\title{
Popliteal entrapment syndrome. A systematic review of the literature and case presentation
}

\author{
Kemal Gokkus ${ }^{1}$ \\ Ergin Sagtas ${ }^{2}$ \\ Tamer Bakalim ${ }^{3}$ \\ Ertugrul Taskaya ${ }^{3}$ \\ Ahmet Turan Aydin 4 \\ 1 Department Orthopaedics, Ozel Antalya Memorial \\ Hospital, Turkey \\ 2 Radiology section, Ozel Antalya Memorial Hospital, \\ Turkey \\ ${ }^{3}$ Cardiovascular Surgery Section, Ozel Antalya \\ Memorial Hospital, Turkey \\ 4 Orthopaedics and Traumatology, Ozel Antalya \\ Memorial Hospital, Turkey
}

\author{
Corresponding author: \\ Kemal Gokkus \\ Department Orthopaedics, \\ Ozel Antalya Memorial Hospital \\ Zafer mah yildirim beyazit caddesi, 91 \\ 07326 Antalya, Turkey \\ E-mail:kgokkus@yahoo.com
}

\section{Summary}

Popliteal artery entrapment syndrome (PAES) is rare in young adults. Claudication of the young patient, which is often overlooked, is a very rare symptom for orthopedic surgeons. In elder patients, the physician might expect atherosclerotic claudication, however in young patients, popliteal artery entrapment syndrome (PAES) should be considered as a possibility in the cases of claudication. Here, an unusual presentation of an uncommon disease that is not widely known by orthopedic surgeons is reported.

KEY WORDS: tendons, circulation, lower limb surgery, muscles, contact sports, popliteal artery.

\section{Introduction}

Popliteal entrapment's anatomical basis was first described by Anderson Stuart in 18791. In 1965, the term "PAES" was coined by Love and Whelan². Popliteal artery entrapment means popliteal artery compression caused by an abnormal anatomical relationship be- tween the vessel and nearby musculotendinous structures or surrounding muscle hypertrophy. This can cause functional impairment ${ }^{3}$ or arterial compression which might lead to chronic vascular microtraumas of arterial wall with possible intramural hematoma or thrombus, distal embolization, aneurysm, dissections and thrombosis with acute distal ischemia in later term ${ }^{4}$. PAES can be explained as the entrapment syndrome of popliteal artery, which is characterized by artery compression secondary to an abnormal relationship of popliteal artery to adjacent muscle and tendons. This is thought to be caused by abnormal embryologic development.

Embryological development of popliteal fossa suggests there is a "competition for more space" between primitive neurovascular bundles and migrating muscle groups g- $^{5}$.

Most common anomalies include incomplete or delayed migration of the medial head of gastrocnemius muscle (MHGM).

The abnormal lateral position of MHGM might cause popliteal artery displacement $2,4,9-11$.

Contraction of a big and powerful muscle in such a limited space, which is bordered by strong fascias and solid bone, results in forced compression of adjacent neurovascular bundle.

Compression and entrapment process may result in repetitive trauma and early atherosclerosis, leading to a decrease in flow of popliteal artery or even occlusion $8,12-15$

The differential diagnosis for patients with exercise induced lower leg pain includes chronic exertional compartment syndrome ${ }^{16}$. Unresolved muscle strain (This classically occurs at the musculotendinous junction of the medial head of gastrocnemius. It is common in middle-aged athletes in racquet sports and is often called 'tennis leg'. On examination, local tenderness over the medial head of gastrocnemius -or which ever muscle is involved- is characteristic) ${ }^{17}$. Medial tibia stress syndrome, fibular and tibial stress fractures, fascial defects, nerve entrapment syndrome, vascular claudication (artherosclerotic or popliteal artery entrapment syndrome) and lumbar disc herniation ${ }^{17}$ (Tab. 1).

With this case presentation, we wanted to emphasize a possibility of popliteal entrapment syndrome in a young man during differential diagnosis of chronic lower extremity pain in young individuals or young athletes. The aim of this study is to remind the orthopedic surgeons about the rare and unusual properties popliteal entrapment syndrome. 
Table 1.

The Table shows differential diagnosis for patients with exercise induced lower leg pain.

\section{MUSCLE-FASCIA ORIGIN}

- Chronic exertional compartment syndrome

- Fascial defects

- Unresolved Muscle Strain

\section{BONE-PERIOSTEUM ORIGIN}

- Medial tibia stress syndrome

- Fibular and tibial stress fractures

\section{NERVE ORIGIN}

- Lumbar disc herniation

(Referred pain arised from the low back )

- Nerve entrapment syndrome

(e.g. of the superficial peroneal nerve as it winds around the head of the fibula)

VASCULAR ORIGIN

- Vascular claudication

(Atherosclerotic or popliteal artery entrapment syndrome)

\section{Case report}

A 22-year-old (R.K) professional wrestler came to our clinic with progressive pain, cramps and paresthesia in his right calf after walking $200 \mathrm{~m}$. The pain had been ongoing for 6 months. The patient was diagnosed with peripheral arterial occlusion, not specified as a popliteal entrapment syndrome, and was followed up with medical treatment for 6 months (oral silostazol, Tab. 2 times in a day), mainly because the first colleague did not suspect popliteal artery entrapment syndrome.

Physical examination revealed pain, palor, tingling and marked tenderness with prominent feeling of fullness in his right calf. All the lower extremity muscles, especially crural muscles were hypertrophic when compared to normal. The peripheral pulses of dorsalis pedis and posterior tibial artery were not palpable even during rest and after the exercises and palor of the cruris was evident after exercises. The perimeter of the right calf is $1.5 \mathrm{~cm}$ less than his left side.

Table 2.

The Table shows the list of selected articles about popliteal entrapment syndrome in the recent literature.

\begin{tabular}{|c|c|c|c|c|}
\hline Patient groups & Articles -Authors & Year & Journal & Article Message \\
\hline \multirow[t]{5}{*}{ Young individuals } & $\begin{array}{l}\text { Bilateral popliteal artery entrapment } \\
\text { syndrome in a young man. } \\
\text { Ellis DA et al. }{ }^{38}\end{array}$ & 2013 & $\begin{array}{l}\text { J Vasc } \\
\text { Surg. }\end{array}$ & $\begin{array}{l}\text { Bilateral popliteal artery entrapment } \\
\text { syndrome in a young man. }\end{array}$ \\
\hline & $\begin{array}{l}\text { Popliteal artery entrapment syndrome } \\
\text { presenting with acute limb ischaemia: } \\
\text { a case report } \\
\text { Soobrah } \mathrm{R} \text { et al. }{ }^{52}\end{array}$ & 2010 & $\begin{array}{l}\text { Case Rep } \\
\text { Med. }\end{array}$ & $\begin{array}{l}24 \text { year old fit and healty } \\
\text {-ex army officer. } \\
\text { Limb threatining condition }\end{array}$ \\
\hline & $\begin{array}{l}\text { Popliteal artery entrapment syndrome. } \\
\text { O'Leary DP et al. }{ }^{49}\end{array}$ & 2010 & $\begin{array}{l}\text { Int J Surg. } \\
\text { Case Rep }\end{array}$ & $\begin{array}{l}\text { The patient } 19 \text { year old femaled and } \\
\text { non smoker }\end{array}$ \\
\hline & $\begin{array}{l}\text { Bilateral popliteal aneurysm as a result } \\
\text { of vascular type IV entrapment in } \\
\text { a young patient: a report of an } \\
\text { exceptional case. } \\
\text { López Garcia D et al. }{ }^{45}\end{array}$ & 2007 & $\begin{array}{l}\text { J Vasc } \\
\text { Surg. }\end{array}$ & $\begin{array}{l}\text { Type } 4 \text { popliteal entrapment by a } \\
\text { fibrous band independent of } \\
\text { gastrocnemius muscle was } \\
\text { diagnosed durin surgery and divided. }\end{array}$ \\
\hline & $\begin{array}{l}\text { A Popliteal artery entrapment } \\
\text { syndrome: diagnosis and management, } \\
\text { with report of three cases. } \\
\text { Radonić } V \text { et al. }{ }^{50}\end{array}$ & 2000 & $\begin{array}{l}\text { Tex Heart } \\
\text { Inst J. }\end{array}$ & $\begin{array}{l}31 \text { years old bus driver } \\
33 \text { year old skilled mechanic } \\
21 \text { year old lorry driver }\end{array}$ \\
\hline \multirow[t]{4}{*}{ Childrens } & $\begin{array}{l}\text { Popliteal arterial entrapment syndrome } \\
- \text { a rare cause of thromboembolic } \\
\text { lower leg ischemia in a 14-year-old. } \\
\text { Chang DH et al. }{ }^{33}\end{array}$ & 2013 & Rofo. & $\begin{array}{l}\text { A rare cause of thromboembolic } \\
\text { lower leg ischemia in a } 14 \text { year old }\end{array}$ \\
\hline & $\begin{array}{l}\text { Popliteal artery entrapment syndrome } \\
\text { in a young girl: case report of a } \\
\text { rare finding. } \\
\text { Molinaro V et al. }{ }^{48}\end{array}$ & 2012 & $\begin{array}{l}\text { Ann Vasc } \\
\text { Surg. }\end{array}$ & $\begin{array}{l}14 \text { year old girl who presented with a } \\
1 \text {-month history of calf claudication }\end{array}$ \\
\hline & $\begin{array}{l}\text { Popliteal artery entrapment syndrome } \\
\text { in a young girl. } \\
\text { Haidar S et al. }{ }^{41}\end{array}$ & 2005 & $\begin{array}{l}\text { Pediatr } \\
\text { Radiol. }\end{array}$ & $\begin{array}{l}11,5 \text { year old girl with trombosed } \\
\text { aneurysm with right popliteal artery } \\
\text { subsequently diagnosed with bilateral } \\
\text { type I PAES. }\end{array}$ \\
\hline & $\begin{array}{l}\text { Acute lower extremity ischemia in a } \\
7 \text {-year-old boy: an unusual case of } \\
\text { popliteal entrapment syndrome. } \\
\text { Bernheim JW et al. }{ }^{32}\end{array}$ & 2004 & $\begin{array}{l}\text { J Vasc } \\
\text { Surg. }\end{array}$ & $\begin{array}{l}\text { Acute lower extremity ischemia in a } \\
7 \text {-year-old boy }\end{array}$ \\
\hline
\end{tabular}


Table 2. (continue)

\begin{tabular}{|c|c|c|c|c|}
\hline Patient groups & Articles -Authors & Year & Journal & Article Message \\
\hline \multirow[t]{4}{*}{ Childrens } & $\begin{array}{l}\text { Popliteal entrapment syndrome: } \\
\text { non-invasive diagnosis and complete } \\
\text { recovery after surgery in an } \\
11 \text {-year-old boy. } \\
\text { Schwarz T et al. }{ }^{51}\end{array}$ & 1999 & $\begin{array}{l}\text { Pediatr } \\
\text { Radiol. }\end{array}$ & $\begin{array}{l}\text { Popliteal entrapment syndrome in an } \\
11 \text {-year-old boy. }\end{array}$ \\
\hline & $\begin{array}{l}\text { Popliteal artery entrapment syndrome. } \\
\text { Case report of an } 11 \text {-year-old boy. } \\
\text { Fitze G et al. }{ }^{39}\end{array}$ & 1997 & $\begin{array}{l}\text { Langenbecks } \\
\text { Arch Chir. }\end{array}$ & $\begin{array}{l}\text { Popliteal artery entrapment syndrome. } \\
\text { Case report of an } 11 \text {-year-old boy. }\end{array}$ \\
\hline & $\begin{array}{l}\text { The popliteal artery entrapment } \\
\text { syndrome in children. } \\
\text { Cummings RJ et al. }{ }^{35}\end{array}$ & 1992 & $\begin{array}{l}\text { J Pediatr } \\
\text { Orthop. }\end{array}$ & $\begin{array}{l}\text { This article reviews } 41 \text { cases of the } \\
\text { popliteal artery entrapment syndrome } \\
\text { in individuals less than } 20 \text { years of } \\
\text { age. Because vascular insufficiency is } \\
\text { uncommon in orthopedic patients in } \\
\text { this age group and this syndrome has } \\
\text { received little attention in the } \\
\text { orthopedic literature, orthopedists } \\
\text { unfamiliar with this relatively easily } \\
\text { diagnosed condition may miss it. }\end{array}$ \\
\hline & $\begin{array}{l}\text { Bilateral popliteal artery entrapment } \\
\text { syndrome-report of a case. } \\
\text { Iwai T et al. }{ }^{42}\end{array}$ & 1978 & $\begin{array}{l}\text { Jpn J } \\
\text { Surg. }\end{array}$ & $\begin{array}{l}\text { A 15-year-old girl presented with } \\
\text { bilateral PAES. }\end{array}$ \\
\hline \multirow[t]{10}{*}{ Sport professionals } & $\begin{array}{l}\text { Exercise-related bilateral leg } \\
\text { atypical claudication in female } \\
\text { olympic taekwondo player: } \\
\text { a case report. } \\
\text { Vilás RO et al. }{ }^{55}\end{array}$ & 2011 & $\begin{array}{l}\text { J Sports } \\
\text { Sci Med. }\end{array}$ & $\begin{array}{l}\text { Functional popliteal entrapment } \\
\text { syndrome }\end{array}$ \\
\hline & $\begin{array}{l}\text { Vascular claudication in a young } \\
\text { patient: popliteal entrapment syndrome. } \\
\text { Roche-Nagle G et al. }{ }^{30}\end{array}$ & 2009 & $\begin{array}{l}\text { Hong Kong } \\
\text { Med J. }\end{array}$ & 34-year-old athletic trainer \\
\hline & $\begin{array}{l}\text { Popliteal artery entrapment syndrome } \\
\text { in } 3 \text { young athletes. } \\
\text { Delgado Daza } R \text { et al. }{ }^{36}\end{array}$ & 1993 & Angiologia. & $\begin{array}{l}\text { Basketball, Football and Roler } \\
\text { Hockey players }\end{array}$ \\
\hline & $\begin{array}{l}\text { Bilateral popliteal artery occlusion in a } \\
\text { competitive bike rider: case report and } \\
\text { clinical review. } \\
\text { McAree BJ et al. }{ }^{3}\end{array}$ & 2008 & $\begin{array}{l}\text { Vasc } \\
\text { Endovascular } \\
\text { Surg. }\end{array}$ & 33-year-old bike rider with PAES \\
\hline & $\begin{array}{l}\text { Bilateral functional popliteal artery } \\
\text { entrapment in a young athlete. } \\
\text { Symeonidis PD et al. }{ }^{53}\end{array}$ & 2008 & Knee. & $\begin{array}{l}\text { 19-year-old Australian football } \\
\text { player }\end{array}$ \\
\hline & $\begin{array}{l}\text { Popliteal artery entrapment syndrome } \\
\text { in an elite rower: sonographic } \\
\text { appearances. } \\
\text { Alvarez Rey I et al. }{ }^{28}\end{array}$ & 2004 & $\begin{array}{l}\text { J Ultrasound } \\
\text { Med. }\end{array}$ & 22-year-old olympic rower. \\
\hline & $\begin{array}{l}\text { Popliteal artery entrapment in a } \\
\text { high school athlete. A case report. } \\
\text { Duwelius PJ et al. }{ }^{37}\end{array}$ & 1987 & $\begin{array}{l}\text { Am J } \\
\text { Sports Med. }\end{array}$ & $\begin{array}{l}\text { Popliteal artery entrapment in a } \\
\text { high school athlete }\end{array}$ \\
\hline & $\begin{array}{l}\text { Intermittent claudication in an athlete- } \\
\text { popliteal artery entrapment: } \\
\text { a case report. } \\
\text { Taunton JE et al. }{ }^{54}\end{array}$ & 1982 & $\begin{array}{l}\text { Can J Appl } \\
\text { Sport Sci. }\end{array}$ & 26-year-old female athlete \\
\hline & $\begin{array}{l}\text { Intermittent claudication in young } \\
\text { athletes: popliteal artery entrapment } \\
\text { syndrome. } \\
\text { Lysens RJ et al. }{ }^{46}\end{array}$ & 1983 & $\begin{array}{l}\text { Am J } \\
\text { Sports Med. }\end{array}$ & $\begin{array}{l}20 \text {-year-old soccer player and } \\
23 \text {-year-old student }\end{array}$ \\
\hline & $\begin{array}{l}\text { Intermittent claudication in young } \\
\text { athletes: popliteal artery entrapment } \\
\text { syndrome. } \\
\text { Darling RC et al. }{ }^{9}\end{array}$ & 1974 & J Trauma. & $\begin{array}{l}\text { Intermittent claudication in young } \\
\text { athletes: popliteal artery entrapment } \\
\text { syndrome. }\end{array}$ \\
\hline
\end{tabular}


Table 2. (continue)

\begin{tabular}{|c|c|c|c|c|}
\hline Patient groups & Articles -Authors & Year & Journal & Article Message \\
\hline \multirow[t]{5}{*}{$\begin{array}{l}\text { Extremely } \\
\text { interesting and } \\
\text { didactic cases }\end{array}$} & $\begin{array}{l}\text { Popliteal artery entrapment } \\
\text { syndrome: an unusual presentation } \\
\text { of a fibular osteochondroma. } \\
\text { Guy NJ et al .40 }\end{array}$ & 2004 & Knee. & $\begin{array}{l}\text { Popliteal artery entrapment } \\
\text { syndrome: an unusual presentation of } \\
\text { a fibular osteochondroma. }\end{array}$ \\
\hline & $\begin{array}{l}\text { Popliteal vascular entrapment } \\
\text { syndrome caused by a rare } \\
\text { anomalous slip of the lateral head of } \\
\text { the gastrocnemius muscle. } \\
\text { Liu PT et al. }{ }^{44}\end{array}$ & 2005 & $\begin{array}{l}\text { Skeletal } \\
\text { Radiol. }\end{array}$ & $\begin{array}{l}\text { Popliteal vascular entrapment } \\
\text { syndrome caused by a rare } \\
\text { anomalous slip of the lateral head of } \\
\text { the gastrocnemius muscle. }\end{array}$ \\
\hline & $\begin{array}{l}\text { The popliteal-artery entrapment } \\
\text { syndrome in a patient using anabolic } \\
\text { steroids. } \\
\text { Lepori M. et al. }{ }^{29}\end{array}$ & 2002 & $\begin{array}{l}\text { N Engl } \\
\text { J Med. }\end{array}$ & $\begin{array}{l}\text { We speculate that the abuse of } \\
\text { anabolic steroids, as a result of their } \\
\text { prothrombotic action and promotion of } \\
\text { muscle hypertrophy, may have led to } \\
\text { the popliteal-artery entrapment } \\
\text { syndrome in this patient. }\end{array}$ \\
\hline & $\begin{array}{l}\text { Popliteal artery entrapment caused by } \\
\text { bony exostosis. } \\
\text { Cook TA et al. }{ }^{34}\end{array}$ & 1996 & $\begin{array}{l}\text { J Vasc } \\
\text { Endovasc } \\
\text { Surg. }\end{array}$ & $\begin{array}{l}\text { Popliteal artery entrapment caused by } \\
\text { bony exostosis. }\end{array}$ \\
\hline & $\begin{array}{l}\text { Popliteal entrapment as a result of } \\
\text { neurovascular compression by the } \\
\text { soleus and plantaris muscles. } \\
\text { Turnipseed WD et al. }{ }^{11}\end{array}$ & 1992 & $\begin{array}{l}\text { J Vasc } \\
\text { Surg. }\end{array}$ & $\begin{array}{l}\text { Popliteal entrapment as a result of } \\
\text { neurovascular compression by the } \\
\text { soleus and plantaris muscles. }\end{array}$ \\
\hline \multirow[t]{2}{*}{ Functional PAES } & $\begin{array}{l}\text { Functional popliteal entrapment } \\
\text { syndrome in the sports person. } \\
\text { Lane R et al. }{ }^{43}\end{array}$ & 2012 & $\begin{array}{l}\text { Eur J Vasc } \\
\text { Endovasc } \\
\text { Surg. }\end{array}$ & $\begin{array}{l}\text { Clinical trial study about functional } \\
\text { PAES }\end{array}$ \\
\hline & $\begin{array}{l}\text { Atypical claudication and functional } \\
\text { popliteal entrapment. } \\
\text { Mathieu L et al. }{ }^{47}\end{array}$ & 2007 & $\begin{array}{l}\text { Presse } \\
\text { Med. }\end{array}$ & $\begin{array}{l}\text { 22-year-old man diagnosed as a } \\
\text { functional PAES }\end{array}$ \\
\hline
\end{tabular}

Doppler ultrasonography revealed increased popliteal artery flow that was consistent with stenosis and MRI and CT angiography revealed a segmental stenosis, post stenotic aneurysm and thrombus of popliteal artery (Fig. 1a,b) which leads embolism to the small crural arteries (Fig. 2a).

On MRI, an abnormal tendinous insertion originating from medial head of gastrocnemius was detected. After a neglected period of 6 months with conservative treatment at other clinics, the patient finally came to our clinic. Based on these clinical and radiological findings, the source of claudication was thought to be popliteal artery stenosis and with the aid of MRI imagining, abnormal tendinous insertion which originates from gastrocnemius medial head was found (Fig. 3a), confirming the diagnosis of popliteal entrapment syndrome.

Surgical intervention (surgical decompression of the popliteal artery and embolectomy with prophylactic four compartment fasciotomies) is considered. Under general anesthesia, patient was set in prone position. The classical $S$ shaped incision is used to cross the flexion crease. The fascia overlying the popliteal fossa is incised, exposing the neurovascular bundle. The abnormal musculotendinous insertion originating from the gastrocnemius medial head was detected between the artery and vein. Following that, myotomy and decompression were performed by orthopaedic surgeons (Fig. 3b). After this procedure, the cardio- vascular surgeons performed arteriotomy and embolectomy. The arteriotomy closed with separated sutures. Following that the patient was set in supine position and the four compartment fasciotomies were performed.

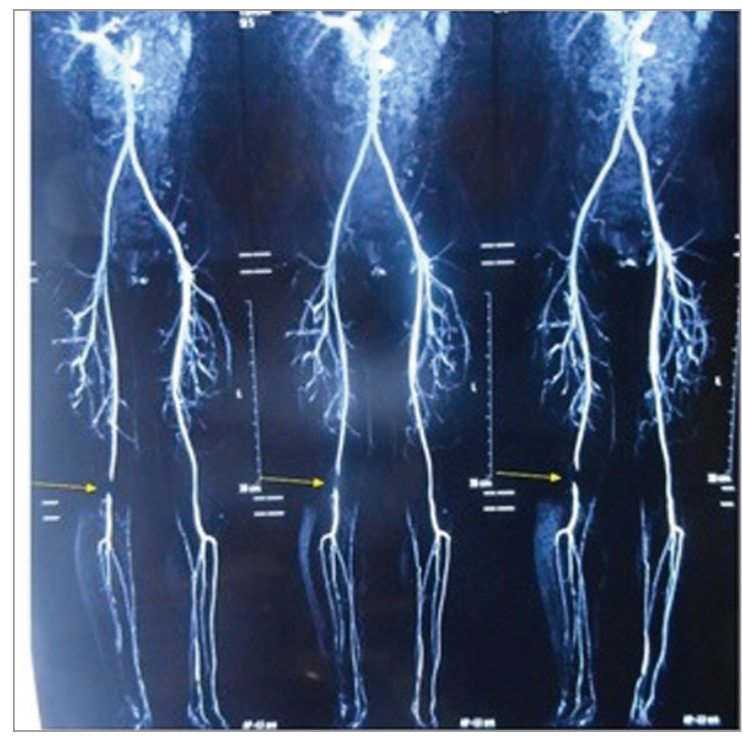

Figure 1a. Pre operative - MRI angiography: the arrows show stenotic segment clearly. Notice the decreased blood flow at distal cruris. 


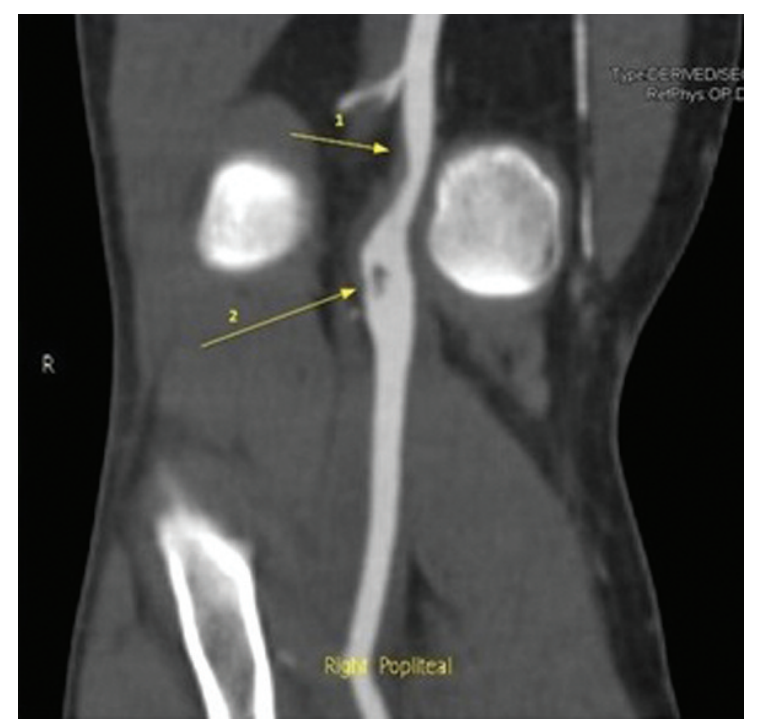

Figure 1b. Arrow 1: popliteal artery stenotic segment; Arrow 2: post stenotic aneurysm and thrombus.

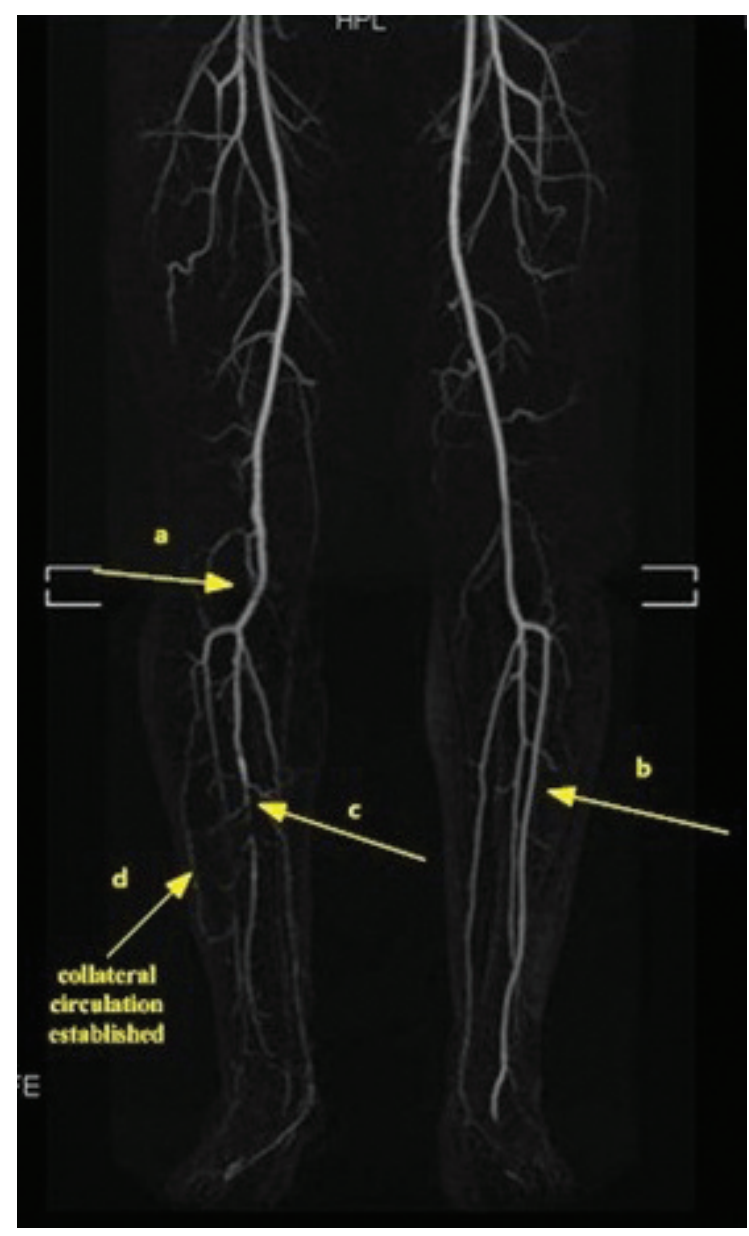

Figure 2b. Post operative angiography; Arrow a shows foot print of previous stenotic segment that totally resolved. Arrow $c$ shows one branch of the trificutaio still occlused but collateral circulation established (Arrow d); Arrow b shows unaffected side.

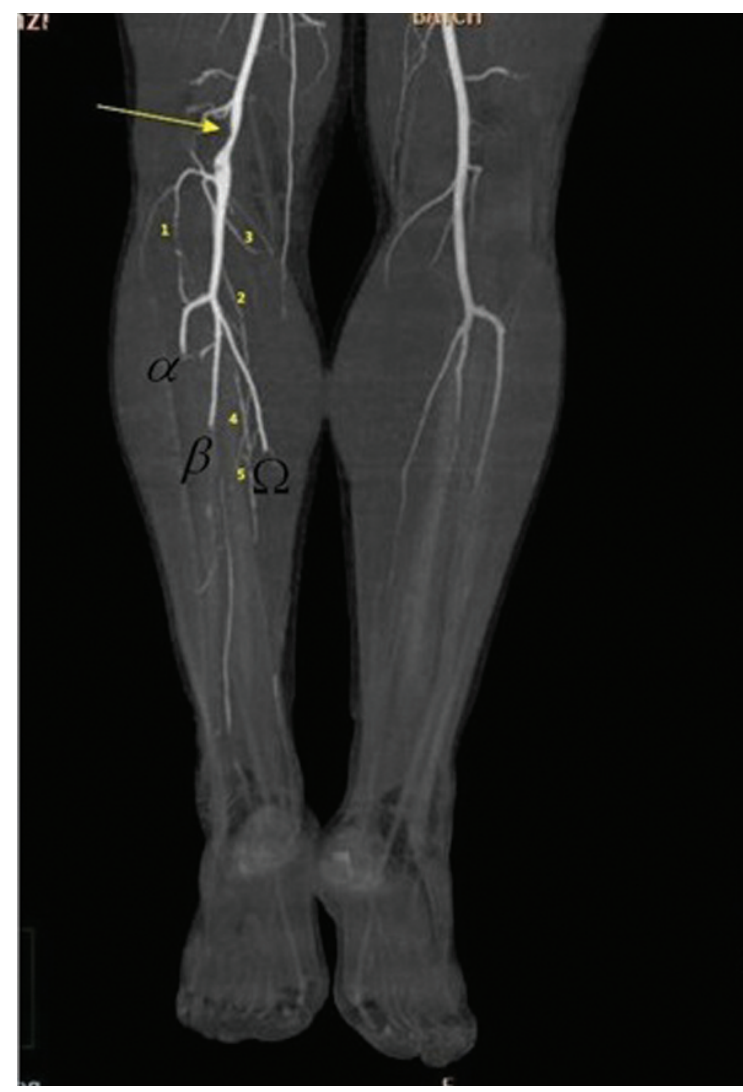

Figure 2a. Ct angiography: 1,2,3,4 numerics show abundant collateral arteries, right popliteal artery is normal. $\Omega$, a, $\beta$ represent distal occlusions due to micro embolism. The arrow shows stenotic segment.

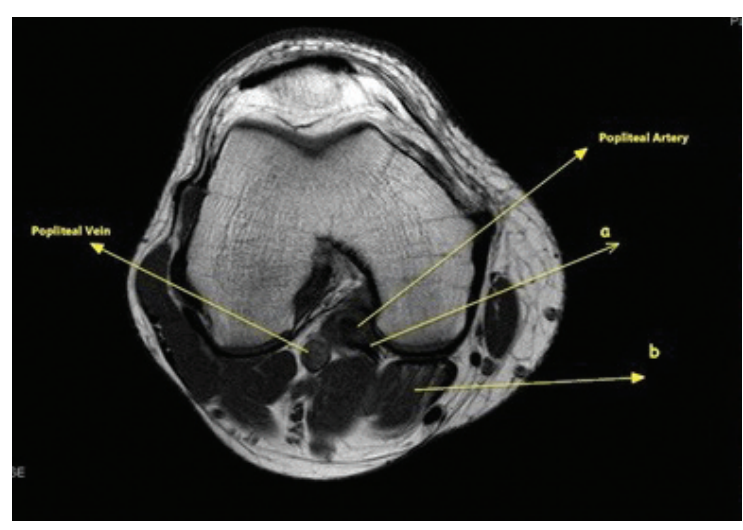

Figure 3a. Arrow a shows abnormal musculotendinous insertion of the medial gastrocnemius head.

(Type 3), Arrow b shows medial gastrocnemius medial head.

Our patient was a professional young wrestler. Following the surgical intervention, pain resolved and patient returned his professional wrestling after two months. No weakness was detected at plantar flexion and no discomfort about the functions of the gastrosoleus group was reported at follow up. 


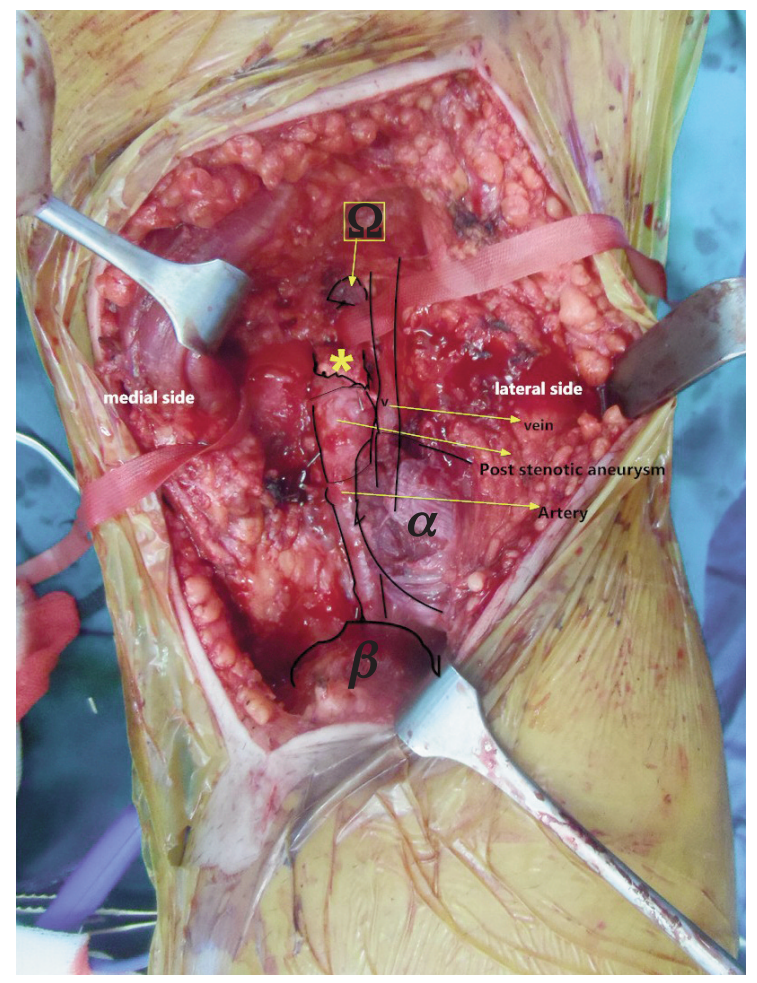

Figure 3b. Omega represents abnormal muscular part of the insertion, originating from medial head of gastrocnemius; Asterisk represents the abnormal fibrous sheat that lies under the abnormal musculo-tendinous insertion. Notice the post stenotic aneurysm. Alpha represents gastocnemius lateral muscle mass hypertrophy and beta represents detached and retracted medial head.

After surgery, vascular claudication resolved rapidly and patient was able to return his professional wrestling career in two months.

We were able to obtain post-operative (4 months after surgery) MRI angiography results of the patient, showing the stenotic segment and occlusion of the distal segments were resolved but one branch of trifucatio remained still occluded. However, the occlusion was compensated by peripheral collateral circulation (Fig. 2,b), as a result of decompression, embolectomy and fasciatomy.

\section{Discussion}

Abnormal embryologic development leads to various anomalous relations in the popliteal fossa that are responsible for entrapment ${ }^{15,18,19}$.

The most widely accepted classification system, proposed by Love and Whelan ${ }^{2}$ and modified by Rich et al. ${ }^{12}$ divides popliteal vascular entrapment syndrome into six types. Type 1 is an aberrant medial arterial course around a normal medial head of gastrocnemius muscle. In Type 2, the abnormal medial head of the gastrocnemius inserts laterally on the distal femur and medially displaces the popliteal artery. In Type 3, the popliteal artery is in its normal position, but an aberrant accessory slip fom the medial head of the gastrocnemius muscle wraps around the popliteal artery and entraps it. In Type 4, the popliteal artery is entrapped by a fibrous band or the popliteus muscle. Type 5 is any form of the first four types that involves the popliteal vein. Type 6, the functional type, has been described in people with symptoms in whom a normally positioned popliteal artery is entrapped by a normally positioned but hypertrophied gastrocnemius muscle. In our case, the patient was classified as a "Type 3" (Fig. 3b).

The differential diagnosis for patients with exercise induced lower leg pain includes chronic exertional compartment syndrome, medial tibia stress syndrome, fibular and tibial stress fractures, fascial defects, nerve entrapment syndrome, vascular claudication (artherosclerotic or popliteal artery entrapment syndrome) and lumbar disc herniation ${ }^{16,17}$.

In our case, physical examination and radiologic imagining studies were all clear, proving popliteal entrapment syndrome. As the surgical intervention certainly showed popliteal artery, we also decided to make a prophylactic fasciatomy in order to prevent the lower limb from compartment syndrome, which can happen following vascular surgery ${ }^{10,} 20$.

The presence of vascular injury more often results in the development of extremity compartment syndrome (ECS) and has been shown to be highly predictive of the need to perform fasciotomy to reduce the risk of limb loss or death 21,22 .

There is an abundance of evidence that treatment of an existing ECS requires urgent and complete fasciotomy and that a delay in treatment results in significant morbidity $22-26$.

The chronic exertional compartment syndrome might be a second possible diagnosis but since we made the decision about the prophylactic four compartment fasciatomy, we did not think this alternative diagnosis might cause us trouble.

In the literature there were a few articles about popliteal artery syndrome that affects young sports participants.

We scanned 390 articles in literature (pubmed from 1965 to 2013). In this scan we mostly selected articles about the young individuals (5 articles), extremely interesting and didactic cases (5 articles), pediatric cases ( 8 articles), Sport professionals (10 articles: female olympic taekwondo player, 34 year old athletic trainer, basketball, Football and Roller Hockey Players, elite rower, competitive bike rider, young athletes), functional entrapment syndromes (2 articles) 3, 6, 9, 11,27-55.

In this point of spectral focus our article might be described as unique about being focused on a professional wrestler.

Also our case will be the first case which popliteal entrapment syndrome in a young wrestler who was treated with both fasciatomy and decompression of popliteal artery with embolectomy. In our case, the post stenotic aneurysm and thrombus which leads to embolism at crural arteries can easily be seen. These late changes can be attributed to the delayed diagnosis. 
Wrestling (Turkish: güreş) is considered as an "ancestral sport" in Turkey, represented foremost by the annual Kırkpınar tournament in oil wrestling ${ }^{56}$.

Our patient was the young participant of the Kırkpınar oil wrestling tournament.

Usually an open fasciotomy for an athlete need to be choice very carefully, we have only one case who treated with embolectomy and prophylactic fasciatomy at this manner (prophylactic fasciatomy to prevent the lower limb from compartment syndrome which can occure after vascular surgery in an athlete). So we need more cases to make a scientific evidence. This was the limitation of our paper.

In conclusion, a physician (Emergency medicine doctors, Orthopedic surgeons, Family doctors, General surgeons, Vascular surgeons) should evaluate unilateral lower extremity pain with his/her existent knowledge, but popliteal entrapment syndrome is a very rare condition and is not widely known by orthopedic surgeons. Popliteal entrapment syndrome has the potential to cause significant morbidity. With this case presentation, we wanted to emphasize a possibility of popliteal entrapment syndrome during differential diagnosis in vascular claudication and chronic pain of the lower extremity. The aim of the surgical intervention is to restore the abnormal relationship between the artery and medial head of gastrocnemius and decompress four compartments in leg.

\section{Acknowledgements}

The authors would like to thank Antalya Memorial Hospital chief of medicine Dr. Sevim Suekinci for providing the necessary settings for the study and to our English editor Taylan Alpaslan for his work.

\section{References}

1. Stuart TP. Note on a Variation in the Course of the Popliteal Artery. J Anat Physiol. 1879;13(Pt 2):162.

2. Love JW, Whelan TJ. Popliteal artery entrapment syndrome. Am J Surg. 1965;109:620-624.

3. McAree BJ, O'Donnell ME, Davison GW, et al. Bilateral popliteal artery occlusion in a competitive bike rider: case report and clinical review. Vasc Endovascular Surg. 2008; 42:380-385.

4. Papaioannou S, Tsitouridis K, Giataganas G, et al. Evaluation of popliteal arteries with CT angiography in popliteal artery entrapment syndrome. Hippokratia. 2009;13:32-37.

5. Colborn GL, Lumsden AB, Taylor BS, et al. The surgical anatomy of the popliteal artery. Am Surg. 1994;60:238-246.

6. Levien LJ. Popliteal vascular entrapment syndrome-cause of leg pain to be considered in young athletes. Sports Med. 2001;1-8.

7. Insua JA, Young JR, Humphries AW. Popliteal artery entrapment syndrome. Arch Surg. 1970;101:771-775.

8. Levien JL, Veller MG. Popliteal artery entrapment syndrome: more common than previously recognized. J Vasc Surg. 1999; 30:587-598.

9. Darling RC, Buckley CJ, Abbot WM, et al. Intermittent claudication in young athletes: popliteal artery entrapment syndrome. J Trauma. 1974;14:543-552.
10. Kronja G, Misović S, Tomić A. Indications and results of fasciotomy in vascular injuries of the lower extremities. Vojnosanit Pregl. 2000;57(3):271-276.

11. Turnipseed WD, Pozniak M. Popliteal entrapment as a result of neurovascular compression by the soleus and plantaris muscles. J Vasc Surg. 1992;15:285-294.

12. Rich NM, Collins GJ, McDonald PT, et al. Popliteal vascular entrapment: its increasing interest. Arch Surg. 1979;114:13771384.

13. Whelan TJ, Haimovici $H$. Vascular surgery: principles and techniques. 2nd ed. New York: McGraw-Hill. 1984; 557-567.

14. Wright LB, Matchett WJ, Cruz CP, et al. Popliteal artery disease: diagnosis and treatment. Radiographics. 2004 24(2):467-479.

15. Zhong $\mathrm{H}$, Gan J, Zhao $\mathrm{Y}$, et al. Role of $\mathrm{CT}$ angiography in the diagnosis and treatment of popliteal vascular entrapment syndrome. AJR Am J Roentgenol. 2011;197(6):W1147-54.

16. Bong MR, Polatsch DB, Jazrawi LM, et al. Chronic exertional compartment syndrome: diagnosis and management. Bull Hosp Jt Dis. 2005;62(3-4):77-84.

17. Locke S. Exercise related chronic lower leg pain. Aust Fam Physician. 1999;28:569-573.

18. Padulo J, Oliva F, Frizziero A, Maffulli N. Muscles, Ligaments and Tendons Journal. Basic principles and recommendations in clinical and field science research. MLTJ. 2013;4:250-252.

19. Elias DA, White LM, Rubenstein JD, et al. Clinical evaluation and MR imaging features of popliteal artery entrapment and cystic adventitial disease. AJR Am J Roentgenol. 2003; 180(3):627-632.

20. Papaioannou S, Tsitouridis K, Giataganas G, et al. Evaluation of popliteal arteries with CT angiography in popliteal artery entrapment syndrome. Hippokratia. 2009;13:32-37.

21. Papalambros EL, Panayiotopoulos YP, Bastounis E, Zavos $G$, Balas P. Prophylactic fasciotomy of the legs following acute arterial occlusion procedures. Int Angiol. 1989;8(3): 120-124.

22. Branco BC, Inaba K, Barmparas G, et al. Incidence and predictors for the need for fasciotomy after extremity trauma: A 10year review in a mature level I trauma centre. Injury. 2010.

23. Farber A, Tan TW, Hamburg NM, Kalish JA, et al. Early fasciotomy in patients with extremity vascular injury is associated with decreased risk of adverse limb outcomes: a review of the National Trauma Data Bank. Injury. 2012;43(9):1486-1491.

24. Finkelstein JA, Hunter GA, Hu RW. Lower limb compartment syndrome: course after delayed fasciotomy. J Trauma. 1996;40(3):342-344

25. Sheridan GW, Matsen FA III. Fasciotomy in the treatment of the acute compartment syndrome. J.Bone Joint Surg Am. 1976;58:112-115.

26. Cargile JS III, Hunt JL, Purdue GF. Acute trauma of the femoral artery and vein. J Trauma. 1992; 32:364-370.

27. Jensen SL, Sandermann J. Compartment syndrome and fasciotomy in vascular surgery. A review of 57 cases. Eur J Vasc Endovasc Surg. 1997;13:48-53.

28. Alvarez Rey I, Alvarez Rey G, Alvero Cruz JR, et al. Popliteal artery entrapment syndrome in an elite rower: sonographic appearances. J Ultrasound Med. 2004;23(12):1667-1674.

29. Lepori M, Perren A, Gallino A. The popliteal-artery entrapment syndrome in a patient using anabolic steroids. N Engl J Med. 2002;346:1254-1255.

30. Roche-Nagle G, Wong KT, Oreopoulos G. Vascular claudication in a young patient: popliteal entrapment syndrome. Hong Kong Med J. 2009;15(5):388-390.

31. Tercan $F$, Oğuzkurt L, Kizilkiliç $\mathrm{O}$, et al. Popliteal artery entrapment syndrome. Diagn Interv Radiol. 2005;11(4):222-224.

32. Bernheim JW, Hanson J, Faries P, Kilaru S, Winchester P, Mousa A, Trost D, Kent KC. Acute lower extremity ischemia in a 7-year-old boy: an unusual case of popliteal entrapment syn- 
drome. J Vasc Surg. 2004;39(6):1340-3. Erratum in: J Vasc Surg. 2005;42(6):1285.

33. Chang DH, Mueller D, Bangard C. Popliteal arterial entrapment syndrome - a rare cause of thromboembolic lower leg ischemia in a 14-year-old. Rofo. 2013;185(5):490-491.

34. Cook TA, Galland RB. Popliteal artery entrapment caused by bony exostosis. Eur J Vasc Endovasc Surg. 1996;11(2):238239.

35. Cummings RJ, Webb HW, Lovell WW, Kay G. The popliteal artery entrapment syndrome in children. J Pediatr Orthop. 1992;12(4):539-541.

36. Delgado Daza R, Moga Donadeu LL, Muncunill Gil J, Mañosa Bonamich J, Vidal Conde V. Popliteal artery entrapment syndrome in 3 young athletes. Angiologia. 1993;45(3):99-102.

37. Duwelius PJ, Kelbel JM, Jardon OM, Walsh WM. Popliteal artery entrapment in a high school athlete. A case report. Am J Sports Med. 1987;15(4):371-373.

38. Ellis DA, Williamson WK. Bilateral popliteal artery entrapment syndrome in a young man. J Vasc Surg. 2013;58(6):1669.

39. Fitze G, Taut H, Rupprecht E, Roesner D. Popliteal artery entrapment syndrome. Case report of an 11-year-old boy. Langenbecks Arch Chir. 1997;382(6):393-397.

40. Guy NJ, Shetty AA, Gibb PA. Popliteal artery entrapment syndrome: an unusual presentation of a fibular osteochondroma. Knee. 2004;11(6):497-499.

41. Haidar S, Thomas K, Miller S. Popliteal artery entrapment syndrome in a young girl. Pediatr Radiol. 2005;35(4):440-443. Epub 2004 Nov 3.

42. Iwai T, Konno S, Okumori M, Matsubara S, Soga K. Bilateral popliteal artery entrapment syndrome-report of a case. Jpn J Surg. 1978;8(3):213-221.

43. Lane R, Nguyen T, Cuzzilla M, Oomens D, Mohabbat W, Hazelton S. Functional popliteal entrapment syndrome in the sports person. Eur J Vasc Endovasc Surg. 2012;43(1):81-87.

44. Liu PT, Moyer AC, Huettl EA, Fowl RJ, Stone WM. Popliteal vascular entrapment syndrome caused by a rare anomalous slip of the lateral head of the gastrocnemius muscle. Skeletal Radiol. 2005;34(6):359-363.
45. López Garcia D, Arranz MA, Tagarro S, Camarero SR, Gonzalez ME, Gimeno MG. Bilateral popliteal aneurysm as a result of vascular type IV entrapment in a young patient: a report of an exceptional case. J Vasc Surg. 2007;46(5):1047-1050.

46. Lysens RJ, Renson LM, Ostyn MS, Stalpaert G. Intermittent claudication in young athletes: popliteal artery entrapment syndrome. Am J Sports Med. 1983;11(3):177-179.

47. Mathieu L, Breda R, Bonnet S, Montagliani L, Duverger V. Atypical claudication and functional popliteal entrapment. Presse Med. 2007;36(11 Pt 1):1581-1584.

48. Molinaro V, Pagliasso E, Varetto G, Castagno C, Gibello L, Zandrino F, Suita R, Rispoli P. Popliteal artery entrapment syndrome in a young girl: case report of a rare finding. Ann Vasc Surg. 2012;26(4):572.e5-9.

49. O'Leary DP, O'Brien G, Fulton G. Popliteal artery entrapment syndrome. Int J Surg Case Rep. 2010;1(2):13-15.

50. Radonić V, Koplić S, Giunio L, Bozić I, Masković J, Buća A Popliteal artery entrapment syndrome: diagnosis and management, with report of three cases. Tex Heart Inst $\mathrm{J}$. 2000;27(1):3-13.

51. Schwarz T, Schellong SM, Neumann U, Traut H, Daniel WG. Popliteal entrapment syndrome: non-invasive diagnosis and complete recovery after surgery in an 11-year-old boy. Pediatr Radiol. 1999;29(2):109-111.

52. Soobrah R, Nawaz A, Hussain T. Popliteal artery entrapment syndrome presenting with acute limb ischaemia: a case report. Case Rep Med. 2010;2010:281925.

53. Symeonidis PD, Stavrou P, King D. Bilateral functional popliteal artery entrapment in a young athlete. Knee. 2008;15(1):54-57.

54. Taunton JE, Maxwell TM. Intermittent claudication in an athlete-popliteal artery entrapment: a case report. Can J Appl Sport Sci. 1982;7(3):161-163.

55. Vilás RO, Rodriguez LÁ, Campos MY, Moran Ade L, Mas FL. Exercise-related bilateral leg atypical claudication in female olympic taekwondo player: a case report. J Sports Sci Med. 2011;10(4):768-770.

56. http://en.wikipedia.org/wiki/Wrestling_in_Turkey 